
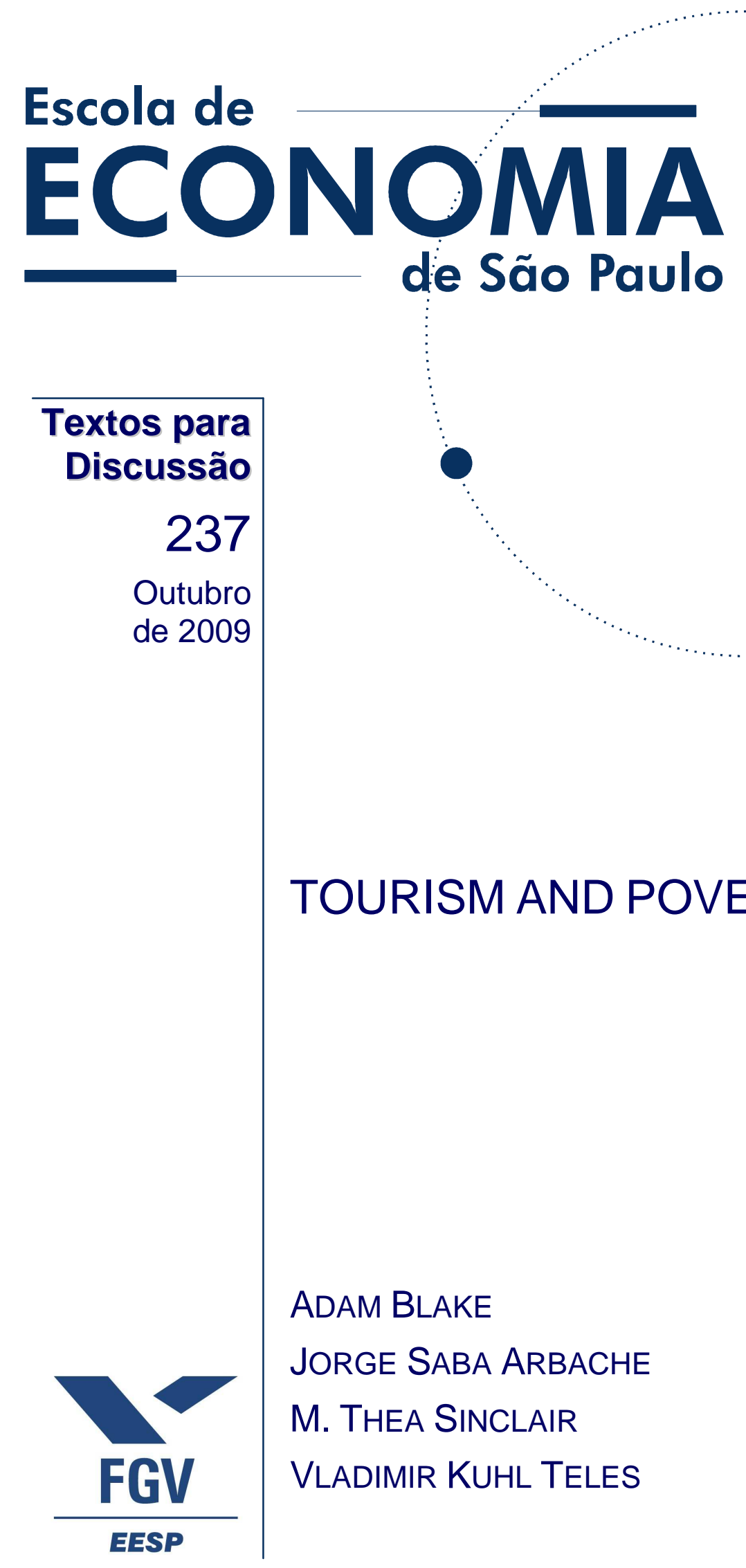
Os artigos dos Textos para Discussão da Escola de Economia de São Paulo da Fundação Getulio

Vargas são de inteira responsabilidade dos autores e não refletem necessariamente a opinião da FGV-EESP. É permitida a reprodução total ou parcial dos artigos, desde que creditada a fonte.

Escola de Economia de São Paulo da Fundação Getulio Vargas FGV-EESP www.fgvsp.br/economia 


\title{
TOURISM AND POVERTY RELIEF
}

\author{
Adam Blake, \\ University of Nottingham, UK, \\ Jorge Saba Arbache,
}

The World Bank, Office of the Chief Economist, Africa Region, and Center for Excellence in Tourism, University of Brasilia, Brazil

M. Thea Sinclair,

University of Nottingham, UK,

Vladimir Kuhl Teles,

Sao Paulo School of Economics, Getulio Vargas Foundation (EESP-FGV), Brazil

\begin{abstract}
This paper examines the issue of how tourism affects poverty in the context of the effects of tourism on an economy as a whole and on particular sectors within it. A framework for analysing the channels through which tourism affects different households is developed, and a computable general equilibrium model of the Brazilian economy is used to examine the economic impact and distributional effects of tourism in Brazil. It is shown that the effects on all income groups are positive. The lowest income households benefit from tourism but by less than some higher income groups. Policies that could redistribute greater shares of the revenue to the poor are considered.
\end{abstract}

Keywords: Poverty relief, Income distribution, CGE

Running Head: Tourism and Poverty Relief

${ }^{1}$ Dr Adam Blake is Assistant Professor in Tourism Economics, Christel DeHaan Tourism and Travel Research Institute, University of Nottingham, Jubilee Campus, Wollaton Road, Nottingham, NG8 1BB, UK. Email<Adam.Blake@nottingham.ac.uk>. Dr Adam Blake, Professor Jorge Saba Arbache, Professor Thea Sinclair and Dr Vladimir Teles undertake research on tourism analysis, modelling and policy formation relating to tourism impacts and their effects on different income groups. 


\section{Tourism and Poverty Relief}

\section{INTRODUCTION}

It is often assumed that tourism provides a means of relieving poverty. Indeed, international organisations such as the World Tourism Organisation often link tourism with potential for poverty relief. However, apart from studies of specific projects and programmes that indicate how tourism can assist poverty relief (for example, Ashley and Roe, 2002), there is little economy-wide research evidence to suggest that tourism does reduce poverty nor studies that quantify the interactions between tourism and poverty. This paper aims to fill part of that gap by providing quantitative measures of the effects of tourism expansion on the distribution of income between the rich and poor in Brazil.

The reason for examining tourism's role in poverty relief derives from the fact that many developing countries have large or potentially large tourism markets. In many countries with high levels of poverty, receipts from international tourism are a considerable proportion of GDP and export earnings (Sinclair 1998, Roe et al., 2004). If tourism receipts are so significant, why might they fail to reduce poverty? The answer is that for some countries they may be assisting poor households but for others, they may be providing disproportionate gains for the rich. Therefore further analysis of the channels through which tourism affects households, and in particular poor households, is necessary.

It is clear that some of the expenditure by tourists in developing countries has no effect on poverty relief because it is spent on imports, or is earned by foreign workers or businesses. These leakages can be high - McCulloch et al. (2001:248) estimate that between 55\% and $75 \%$ of tourism spending leaks back to developed countries. The leakage of foreign currency, particularly through imports, is long-recognised in the economic impact literature, with reviews by Fletcher (1989), Wanhill (1994) and Archer (1996). Traditional impact studies take account of such leakages but are insufficient on their own to tell us about poverty relief.

The effects of tourism on poverty relief can be examined using a conceptual framework involving three channels - prices, earnings and government revenue - previously considered in the context of the effects of trade liberalisation on poverty (McCulloch et al., 2001). A computable general equilibrium (CGE) model is used to quantify the effects on income 
distribution and poverty relief that occur via these channels. The model has become a well accepted approach in tourism modelling (Dwyer et al., 2004) but differs from the CGE modelling approaches that have been used to examine tourism to date, in that it is extended to incorporate the earnings of different groups of workers within tourism, along with the channels by which changes in earnings, prices and the government affect the distribution of income between rich and poor households. The model has the advantage of incorporating the entire range of activities undertaken in the economy, thereby permitting analysis of the interrelationships between tourism and other sectors of the economy. It is developed, for the case of Brazil, to incorporate data for the earnings received by households with different income levels. Such models perform well relative to other modelling approaches when analysing poverty impacts (Kraev and Akolgo 2005)

The paper provides a context for the analysis by discussing tourism and poverty relief, as well as literature on tourism impact modelling. The ways in which tourism affects the distribution of income to poor households via the channels of prices, earnings and the government are examined and a CGE model is developed to take account of both the impact of tourism expansion and the distributional effects among rich and poor households. The model differs from fixed-price analyses, such as input-output and SAM multiplier methods, by allowing prices and wages to alter, satisfying resource constraints and by accounting for government budget constraints. An increase in demand tends to have lower macroeconomic effects in CGE models than in fixed price approaches because resources move from other industries into industries stimulated by the demand increase, so that some of the gains of fixed price approaches are traded off against losses in other industries (Dwyer et al., 2004). This means that while fixed price approaches are able to examine earnings channels through a rather narrow definition of direct and indirect impacts, CGE models can also analyse price and government channels, and include a broader range of earnings channels effects through industries that may decline as a result of tourism expansion.

The model is used to examine the effects of tourism on poverty reduction using data for Brazil, indicating related conclusions and policy implications. The modelling framework could be applied, in future research, to other countries which are concerned to know about the distributional effects of tourism. 


\section{TOURISM IMPACT AND POVERTY RELIEF}

Poverty relief has rarely been discussed in the context of the distributional effects of tourism across the economy as a whole. Aspects of poverty can include low incomes, low levels of wealth, a poor environment, little or no education and vulnerability (McCulloch et al, 2001:38). Low income levels are one of the main ways in which poverty is measured, with absolute levels of poverty often demarcated by the \$1-per-day line in cross-country comparisons. Wealth is another economic aspect of poverty; households may have incomes above $\$ 1$ per day, but be heavily indebted with few assets.

Tourism's potential as a means of achieving poverty reduction is related to the fact that only some of the least developed countries in the world have significant levels of tourism receipts. In the majority of these countries, which are mainly in sub-Saharan Africa, tourism receipts are less than 5\% of GDP (World Bank, 2005; World Tourism Organisation, 2005). Notable exceptions are Cambodia (10.4\%), Eritrea (11.6\%), the Gambia (18.6\%) and Mongolia $(12.1 \%)$. In a larger number of cases, however, tourism receipts are a significant proportion of exports - there are seven countries where the ratio of receipts to exports is over $20 \%$ and twenty countries where this ratio is over $10 \%$. While this is as much a result of the low export to GDP ratio in much of sub-Saharan Africa as of the small size of the tourism sector, it does indicate that tourism revenues are important as a source of foreign currency earnings in many of these countries.

Differences in the distribution of income can lead to higher poverty headcounts in middle income countries with high levels of inequality than in low income countries with a more equal distribution of income. Brazil, the country that will be considered in more detail in this paper, is in the lower middle income developing countries group with $8.2 \%$ of the population living on less than \$1-a-day. This is higher than in Brazil's southern neighbours Argentina $(3.3 \%)$ and Uruguay (2.0\%), but lower than in other South American countries such as Paraguay (16.4\%), Venezuela (14.3\%), Peru (18.1\%), Bolivia (14.4\%) and Ecuador (17.7\%). Brazil has a lower level of tourism receipts relative to GDP, at $0.5 \%$, than most other South American countries: Argentina (1.8\%), Uruguay (3.6\%), Paraguay (1.3\%), Peru (1.6\%), Bolivia (2.2\%), Ecuador (1.5\%) and Colombia (1.4\%). Only Venezuela (0.4\%) has a lower level of tourism receipts as a proportion of GDP, which may be due to Brazil and Venezuela having greater export alternatives through oil production and, in Brazil's case, a more industrialised structure of production. Although the incidence of poverty in Brazil is not particularly high by global standards, in proportional terms, the number of poor is high and 
the potential for tourism to contribute to poverty relief is higher than in countries which lack the infrastructure required for tourism development.

\section{Literature on Tourism Impact Modelling}

Many studies have used input-output (IO) models to estimate either the direct and indirect, or the direct, indirect and induced impact of tourism (Archer, 1995; Fletcher 1989; Wanhill 1994; Archer 1996; Archer and Fletcher, 1996). More recently, it has become clear that tourism spending affects an economy by raising prices and wages and changing the real exchange rate (Dwyer et al., 2004; Blake et al., 2006). These effects differ from the more traditional input-output model multiplier effects because they take account of resource constraints. This has led some researchers to use Computable General Equilibrium (CGE) models that take such effects into account (Adams and Parmenter 1995; Zhou et al. 1997; Blake 2000; Dwyer et al., 2000, 2003a; Sugiyarto et al. 2003).

The case of Australia is examined in a pioneering study by Adams and Parmenter (1995), who quantify the effects of tourism on the industrial and regional structures of the economy. Their results show that traditional export sectors can be crowded out by the growth of international tourism. Zhou et al. (1997) subsequently point out the advantages of the CGE modelling approach relative to IO analysis in a study of the impact of a change in visitor expenditure in Hawaii. They show that IO analysis may over-estimate the magnitude of the impact, as it fails to take account of inter-sectoral resource reallocation effects. A CGE modelling approach is used by Alavalapati and Abramowicz (2000) to examine tourism impacts in regions that are used for resource extraction. Their results indicate the model's use in simulating the effects of a policy change, such as an environmental tax.

Blake (2000) develops a CGE model of the Spanish economy. He shows that increasing the level of taxation on foreign tourism can result in a rise in welfare in Spain, partly owing to the low levels of tax on domestic tourism. Gooroochurn and Sinclair (2004) find that taxing tourism in Mauritius is more efficient and equitable than taxing other sectors, and that taxing highly tourism-intensive sectors generates more revenue from tourism than taxing all tourismrelated sectors. Sugiyarto et al. (2003) use a CGE modelling approach in the context of trade liberalisation measures for the Indonesian economy and show that tourism growth enhances the beneficial effects of trade liberalisation. The effects of exogenous shocks such as foot and mouth disease (Blake et al., 2003) and September 11 (Blake and Sinclair, 2003) are examined 
using CGE models of the UK and the US economies respectively. The results provide useful information for policy makers who need to manage the impacts of such shocks.

CGE modelling has supplanted IO modelling in Australia, owing to widespread awareness of the flexibility of CGE modelling in approximating real world conditions, such as price and wage flexibility and inter-sectoral resource mobility (Dwyer et al., 2003a, 2004). Studies include the effects of inbound tourism under different macroeconomic conditions (Dwyer et $a l ., 2000)$ and the impact of tourism growth, at global, interstate and intrastate levels, on New South Wales (Dwyer et al., 2003b). The modelling technique takes account of economic interrelationships between and within different areas, thereby providing more accurate results and demonstrating the advantages of collaborative policy formation between different areas.

However, as yet, virtually no attention has been paid to the contribution that CGE modelling can make in addressing the important issue of the effects of tourism on income distribution and poverty relief. This paper addresses this issue by integrating a CGE model with data for employee remuneration in different economic sectors so as to quantify the distributional effects of tourism receipts. These effects take place via the channels of changes in prices, earnings and government revenue and expenditure, discussed below.

\section{Study Methods}

The impact and distributional effects of tourism are examined using a CGE model of tourism. The model predicts, through a numerical simulation approach, how changes ('shocks') affect the economy, under the assumptions of price adjustment and factor mobility. The analysis takes explicit account of the channels by which tourism expenditure affects income distribution (McCulloch et al. 2001). The first channel is prices, by which tourism spending leads to changes in prices for goods that poor households purchase. The second channel is that tourism spending leads to changes in earnings for employed and self-employed labor and in returns to capital. The third channel is government, by which tourism spending changes government revenues and can therefore lead to changes in government spending, borrowing or tax rates.

The effects of tourism on these channels depend on the ways in which tourism spending affects the wider economy. Tourists consume a variety of goods and services, some of which are produced by different industries, while others are imported. The effects on earnings and employment in the industries that produce goods that tourists purchase are termed the 'direct 
impact'. These industries purchase other goods and services as part of their production processes and these, in turn, are produced by other industries or imported. Thus, there is a supply chain of industries that produce goods that ultimately satisfy tourist consumption; the effects of tourism on an economy through this supply chain are termed the 'indirect effects'. As domestic residents earn money from this activity, and part of these extra earnings is spent on domestically produced products, there is a further, third round, of effects termed 'induced effects'.

Tourism consumption usually leads to increased output, prices and wages in the industries that sell products directly to tourists. Increases in wages in these industries mean that other industries pay higher wages in order to retain labor (the same applying to capital and capital earnings). This increases the costs and, therefore, prices for other products. The overall increase in domestic prices relative to foreign prices is an appreciation of the real exchange rate. This makes it harder for other industries to export, so output falls in other exporting industries. Industries that produce products not directly consumed by tourists or directly exported in significant volume experience a mix of effects. Some of these industries produce goods that are used in the supply chain of tourism industries and expand when tourism consumption expands. Other industries are linked to the supply chain of traditional export goods, and decline. Industries that are not linked to either tourism or other export activities are likely to have a small increase in demand, as domestic income levels and therefore consumption, rise (the induced effect); but also have increased costs because of the competition with tourism sectors for labor and capital. These industries may have small increases or decreases in output. Therefore poor households are likely to be negatively affected via the price channel; rising prices will reduce real income levels.

It is useful to consider the impacts through the price channel in terms of relative price changes. The largest increases in prices that result from tourism are, in general, for the types of goods and services that tourists consume. These are goods and services that domestic residents only usually consume if they take a domestic trip (accommodation, passenger transport, tour agency and operation services, recreational services and souvenir goods). Exceptions include restaurants and purchased food products. Most of the products (those purchased on domestic trips and restaurant meals) are those purchased more by higher income households; the direct effect of the price channel will, therefore, lead only to small increases in prices paid by poor households, through food products. Even in this case, tourists tend to purchase a different set of food products from those consumed by poor households. 
The earnings channel includes income earned from employment, self employment and capital income. Poor households can benefit from the higher wages and increases in production in tourism related industries. This effect might be moderate, however, if the poor households lack the skills required for employment in tourism related industries. Larger earnings effects may accrue to middle-income households which have skills required in these industries. An offsetting earnings effect comes from the fall in production and wages in traditional export sectors. An adverse aspect of tourism expansion is that if the poor rely heavily on earnings from commodity export sectors, an increase in tourism demand may lead to an increase in poverty. The earnings channel also involves dynamic effects; tourism does not simply change the relative wages of different factors of production, or types of labor, but can induce households to train, and thereby move out of low-skilled employment.

The third channel by which tourism affects household incomes and poverty is via government income. Tourism growth increases government revenues through taxes and charges specifically levied on travel (departure taxes, passenger duties and visa charges), accommodation (hotel bed taxes) and other sources of revenue from attractions (user charges). It also increases revenues from more general taxes on products (value added taxes, sales taxes, excise duties) and on income (income taxes, corporation taxes). As some sectors, particularly export sectors, may experience declines in production, tax revenues from these sectors may decline, and if other export sectors have particularly high tax rates, the overall fiscal position of the government may worsen. However, in general an increase in tax revenues is likely.

Tourism may increase government revenues, but the distribution of the expenditure of the increased revenues is uncertain. The increased revenues are likely to be absorbed into the government deficit (or surplus) in the short run. In the longer run, governments make discretionary decisions on how to reallocate this income stream; some reduce other taxes, some use the revenues to pay off foreign debts, while others increase spending. Other governments may use this revenue on poverty relief programmes. The empirical section of this paper will consider the effects of different ways in which the government spends its increased revenues, to examine whether significantly different outcomes result from different patterns of spending.

The CGE model that is developed incorporates first three channels by which tourism affects the distribution of income. Consumption and production behaviour are modelled using constant elasticity of substitution (CES) functions and constant elasticity of transformation 
(CET) functions. The model is calibrated so that it replicates a benchmark equilibrium for the base year, using data for the base year from the social accounting matrix (SAM) for the Brazilian economy, discussed below. The structure of production in each of the sectors in the model is such that for each commodity $\mathrm{i}$, a sector exists that uses factor services (labor and capital) and intermediate inputs to produce domestic output. On the supply side, 54 commodities and 54 sectors are considered. Imports are added to domestic output to produce market supply. Aggregate supply is sold to either the export market or the domestic market and commodities differ between the export and domestic markets. For some commodities, export volumes are a function of prices (when the country is a large producer in its export markets), and for other commodities domestic prices are equal to the domestic currency value of world prices (when the country is small relative to the total market size).

Factor supplies consist of capital and five types of labor - skilled, semi-skilled, unskilled, self employed and employers. In order to account for the substantial degree of heterogeneity in the skills required in different industries, the supply of factors including capital is subject to imperfect transformation between industries. Thus, labor or capital moves between industries only in response to wage changes, and that the degree of factor movement is determined by the extent to which the relative wage between industries changes.

On the demand side, the model includes foreign tourism demand, household consumption which includes domestic tourism, demand by firms, and domestic and foreign investment. Tourism demand is modelled using a constant elasticity of demand function, whereby the country faces a downward-sloping demand curve for its tourism exports, where foreign tourism consumption is related to the average price paid by foreign tourists and the exchange rate. Tourism consumption involves purchases of different commodities, with a CobbDouglas function determining how tourists substitute between commodities. This means that the share of tourism expenditure on purchases of each commodity is constant.

The manner in which changes in the rest of the economy affect tourism can be traced through the effects of these changes on prices and, hence, on the overall price that tourists pay. The way in which a change in tourism demand affects the economy is by raising demand for the individual commodities that tourists consume. This then, through the rest of the model, leads to changes in prices and further effects on the total price paid by tourists, tourism consumption in total and the demand for individual commodities. 
Each household earns income from factor payments, (net) transfers from abroad, profits from firms, social security payments and other transfers from the government. Each household pays income tax, so that disposable income is equal to income minus the tax rate for that household. Income is allocated to tourism consumption, non-tourism consumption and savings. The consumption types are Cobb-Douglas functions of individual inputs. Firms receive income from factor services (capital), payments (earnings) from abroad, transfers from firms, government and households as represented in the social accounting matrix. Some types of spending by firms are fixed in real quantities (so that when prices change the nominal value of spending changes); other types of spending are a fixed proportion of the remaining income, and other types of spending by firms are proportional to the remaining income, for example income tax payments, investment by firms and profits.

Domestic investment is undertaken using inputs of different commodities in a Cobb-Douglas nest and is equal to the amount of savings by different households, firms and foreign investment. Foreign investment consists of an inflow of foreign currency and purchase of domestic capital and is determined by a constant elasticity relationship between foreign investment and the rate of return on capital. The government collects tax revenues, purchases public goods, makes transfer payments to households, pays interest on foreign debt and makes a contribution to the social security account. Government consumption is fixed and any net surplus is transferred to households through transfers. The exchange rate adjusts to ensure that there is a balance of payments, which can also be viewed as the market clearing condition in the foreign exchange market.

In order to assess how a simulation affects households, an appropriate measurement of welfare is used. The generally accepted measure is termed the equivalent variation $E V_{h}$, which because firms re-investing some profits, and also so that closure rules can be changed to allow foreign debt repayment, is augmented to include benefits to each household accruing from enterprise and government saving, so a further new development of the analysis involves augmenting the $E V_{h}$ calculation to include these effects by calculating a compensated equivalent variation measure $E V_{h}^{*}$ :

$$
E V_{h}^{*}=E V_{h}+\varphi_{h}^{E} \Delta S_{F}+\varphi_{h}^{G} \Delta F
$$


where $\varphi_{h}^{E}$ is the proportion of enterprise savings $S_{F}$ that provide utility or future earnings to household $\mathrm{h}\left(\sum_{h} \varphi_{h}^{E}=1\right)$ and is set according to levels of savings in the SAM. The term $\varphi_{h}^{G}$ is the share of government debt repayments $(\Delta F)$ that provide utility to household $\mathrm{h}$ $\left(\sum_{h} \varphi_{h}^{G}=1\right)$. If future debt would have to be paid by income tax payments, $\varphi_{h}^{G}$ would be set equal to each household's share in income tax payments. Total equivalent variation, showing the net benefits of a simulation to the economy as a whole, is a linear sum of $E V_{h}^{*}$.

\section{Modelling the Distributional Impact of Tourism in Brazil}

Brazil is an interesting country for gaining a better understanding of whether tourism favors the poor. Although it experienced one of the highest average growth rates during the last century, it remains thoroughly rooted in the developing world. The poor have limited - and at times no - access to government services such as health, education and sanitation, and limited participation in the formal labor market. Consequently, they are generally not covered by labor legislation or by most social protection schemes. Poverty is widespread in urban and rural areas, reaching the highest levels in rural parts of the northeast region. Various forms of deprivation, growth of favelas (shanty towns), urban violence, street children and disease have been common not only in large, but also in medium-sized and small cities all over the country. The social problems and the limited effectiveness of government policies in tackling the problems have caused considerable concern and a call for urgent policies to promote growth and create jobs. In 2002 more than half of the labor force was employed in the informal sector, unemployment was about $12 \%$, and the real average wage had lost 15 per cent of its purchasing power compared with 1997. Erro! A origem da referência não foi encontrada.

The Brazilian government sees tourism as a major potential source of job creation and reduction of economic disparities, and long term policies to improve the tourism industry in the country have been established (Minestério do Turismo, 2003). The number of foreign tourists arriving in the country increased from 1.1 million in 1990 to 4.1 million in 2003 . The government expects that about 1.2 million jobs will be created in tourism businesses in four years, should the tourism industry continue to grow. Although tourism comprises a significant 
share of Brazil's GDP, 4.3\% in 2002 (Arbache et al., 2004), it is unclear whether and how tourism will fulfil expectations in terms of job creation and poverty reduction. It is apparent that the benefits from tourism development are concentrated in specific areas of the country, such as Rio de Janeiro, Bahia and the Pantanal, while some of the poorer areas in the northeast are less advantaged. When data become available, further research could investigate the distribution of the returns from tourism within a spatial context.

In contrast to the economy as a whole, the distribution of the income generated in the tourism industry is highly biased in favour of labor, particularly the self-employed, as shown in Figure 1. Only $13 \%$ of the income from tourism accrues to capital, while the share is about $55 \%$ in the economy as a whole. Lower income households also tend to derive a larger proportion of their incomes from tourism activities than higher income households. These two pieces of evidence suggest that tourism can play an important role in poverty reduction in Brazil.

\section{[INSERT FIGURE 1 AROUND HERE]}

The CGE model for tourism in Brazil is calibrated using a SAM that shows the payments that take place between the different industries, products, factors, households, firms, the government and the rest of the world. The SAM was constructed (Arbache et al. 2004) for the specific purpose of developing a CGE model to examine tourism and distributional effects. It contains data for 54 industries, six factors of production and four household groups and is unique in several aspects. Firstly, it is the only input-output database constructed for a lower income country with an emphasis on showing the relationships between tourism related industries (including, for instance, separate accounts for accommodation, recreational services, travel agents and twelve categories of transport services). Such relationships have previously been considered only in higher income countries. Secondly, it is unique in showing the relationships between tourism related industries, different types of labor and different households. The data show how much of each type of labor is employed in each industry, and how much each household earns from each type of labor. This allows us to trace production effects through to their impacts on different household groups. Third, the database is a complete SAM that includes tourism and tourism related industries together with household accounts. Although Tourism Satellite Accounts were not available, the SAM that was constructed provides measures of the different types of tourism activities using the most recent data available in Brazil, in line with the TSA methodology. 
The information included in the SAM enables identification of the impacts of tourism expansion on different household groups, different components of the labor force and on income inequality. The construction of this type of SAM for other developing countries would be useful in providing comparative evidence and in assisting policy formation. While there is no official national definition of a poverty line in Brazil, the SAM is constructed so that the lowest income household with earnings of less than $\mathrm{R} \$ 100$ per capita per month corresponds to a poverty line that has been widely used in official and academic circles, largely because it corresponds to the means-test in Brazil's main cash assistance program (Ferreira et al 2006).

Some summary measures from the SAM and for an input-output analysis of tourism demand in the SAM are provided in Table 1. Measures for Brazil as a whole are given in the first column. Most of the capital is obtained from domestic sources as, even in good years, annual net foreign direct investment accounts for no more than $0.5 \%$ of GDP and most foreign savings have been short-term portfolio capital. The direct and indirect impacts of tourism are in the second column and the ratio of the tourism sector to the whole economy is in the third column. The direct and indirect size of the tourism sector is 77.58 billion Reales, and accounts for just over $5.5 \%$ of total GDP generated in the economy.

\section{[INSERT TABLE 1 AROUND HERE]}

'Remuneration' shows the value of earnings under six categories. Three are labor employment categories distinguished by the level of qualification - skilled, semi skilled and unskilled. Together, these three employed labor categories account for $74 \%$ of all labor earnings in the economy. The other three categories are self employed labor, employers and capital earnings. For the Brazilian economy as a whole, capital earnings and earnings by qualified labor are the two most significant forms of earnings. The tourism sector exhibits higher earnings ratios in self employed labor (13.25\%), semi qualified labor (7.29\%) and non qualified labor $(6.13 \%)$ and a notably low earnings ratio for capital $(0.67 \%)$. The ratio of capital to labor earnings is 1.37 for the economy as a whole, and just 0.12 for tourism.

Tourism contributes $\mathrm{R} \$ 8.58$ billion in indirect tax revenues, 5.32\% of the national total, which is a similar ratio to the GDP ratio - indicating that indirect taxes are on the whole levied at a lower rate on tourism than on the rest of the Brazilian economy.

It is interesting to note that the tourism sector also plays an important role in the distribution of Brazil's income. The evidence is that tourism consumption (for example, domestic tourism) is mainly concentrated upon the wealthiest sections of society - the high income 
households spend $\mathrm{R} \$ 40$ billion per year on domestic tourism, more than twice the value of tourism consumption of all other households combined. On the other hand, the remuneration of households through the tourism sector is increasingly concentrated, in relative terms, towards the lowest and low income households which together receive $\mathrm{R} \$ 14.5$ billion, almost half of all household earnings from tourism ( $\$ 30$ billion). These data show that the nature of the tourism sector implies a distribution of income from the richest, through consumption, to the poorest, through remuneration. It is notable that the largest inter-household flows are from high income households to low income households, but not to the lowest income households.

\section{[INSERT TABLE 2 AROUND HERE]}

Twelve of the fifty-four commodities in the SAM are classified as being tourism related, and both foreign and domestic tourism are classified as being expenditure by tourists on these twelve commodities. Table 2 shows the shares of foreign, domestic and total tourism expenditure as a percentage of total commodity demand, as well as showing how both foreign and domestic tourism spending is shared across these commodities. Notably, foreign tourism expenditure is much more heavily weighted towards expenditure on hotels and other temporary lodging while domestic tourism is more weighted towards regular airline transportation and recreation, cultural and sports services. Tourism's share of commodity demand ranges from $17 \%$ (for travel agencies, of which outbound demand is not included here) to $85 \%$ (for restaurants and other food service enterprises).

\section{Results}

The key issues examined in the model are the economic impacts and distributional effects of tourism expenditure. All the simulations reported here involve a $10 \%$ increase in demand by foreign tourists in Brazil. The increase in demand leads to a variety of effects in the Brazilian economy. These include rises in the prices that tourists pay for goods and services which lead to a fall in demand that counteracts part of the original 10\% increase. Wages in Brazil are also sensitive to changes in demand; average unemployment has been around $10 \%$ over the last five years and real wages have fluctuated in accordance with economic conditions during this period. The tourism demand expansion also leads to changes in production in all industries, changes in employment, earnings, household incomes, prices and all other variables in the model. Table 3 shows the effects that the tourism demand shock has on some of the key variables: tourism consumption, prices and expenditure, equivalent variation for Brazil as a 
whole, compensated EV for the four household groups and the ratio of real income in the highest income household to the lowest income household.

The results from four simulations are included in Table 3. The differences between these simulations are in the way that the government allocates the additional tax revenues that it receives directly and indirectly from the tourism expansion (net of falls in revenue from other activities). In each of these simulations, additional government income is transferred to households - either through increases in transfer payments or through reductions in direct tax levels. In simulation 1, additional revenue is transferred to households in proportion to their original receipts of government transfers. In simulation 2, it is transferred according to households' levels of tax payments (for example, reducing income taxes). In simulation 3, revenues are transferred in proportion to income levels, while in simulation 4 all additional revenues are transferred to the poorest household group.

\section{[INSERT TABLE 3 AROUND HERE]}

The results for tourism and the macroeconomic results are very similar for the four simulations. The $10 \%$ increase in foreign demand leads to increases in prices of, on average, around $0.7 \%$, which reduces the increase in tourism consumption to around $8.5 \%$. Expenditure increases by around $9.2 \%$. In each simulation the resulting increase in tourism expenditure is around 0.68 billion Reales. The welfare benefit to Brazil of this additional expenditure is around $\mathrm{R} \$ 0.309$ billion, implying that Brazil benefits by $\mathrm{R} \$ 45$ for every $\mathrm{R} \$$ 100 spent by tourists; i.e. that there is a multiplier of $0.45(0.309 / 0.680)$.

There are considerable differences in the redistributive effects of the different simulations however. Simulation 1, by transferring additional government revenues to households in proportion to their original receipts of transfer income, essentially maintains the current system of government payments but at a higher level.

Simulation 2, by transferring revenues in proportion to income tax payments is equivalent to the government choosing to spend the revenue gains from tourism expansion on income tax cuts. These two simulations have similar effects on the compensated EV of the lowest income household ( $\mathrm{R} \$ 0.053$ billion) and on the ratio of income levels for the highest and lowest income household, which falls by $0.035 \%$, so that the level of income inequality by this measure is reduced, and the lowest income household is catching up with the highest.

Simulation 3, by transferring revenues to households in proportion to their income levels has somewhat different effects on the distributional effects of tourism expansion. The welfare 
gain for the lowest income household is slightly higher, at $\mathrm{R} \$ 0.058$ billion, with a greater reduction in income inequality $(0.039 \%)$. The reason for the effect of this simulation being larger is that the lowest income household has a much higher share of income $(8.5 \%)$ than either income tax payments $(0.2 \%)$ or government transfers $(0.5 \%)$.

In simulation 4 all additional government revenues are transferred to the lowest income household. In this case, the distributional impacts are significantly different from the other three scenarios, although the macroeconomic impacts are very similar, with a slightly lower welfare gain for Brazil as a whole ( $\mathrm{R} \$ 0.305$ billion compared to $\mathrm{R} \$ 0.309$ billion). By allocating transfers to the lowest income household, the benefit of tourism expansion to this group is doubled, and the poorest household gains around $R \$ 1$ for every $R \$ 7$ spent by foreign tourists in Brazil.

The impact of tourism expansion on different sectors of the economy is similar in all four simulations. Many factors in the economy determine how a sector is affected by tourism expansion, but the main factors are: (i) sectors whose products/services are consumed by tourists expand; (ii) sectors supplying goods that are used in the first group of sectors also expand, but typically by smaller percentages; (iii) sectors that produce export goods contract; and (iv) sectors producing goods used in export sectors also contract, but by smaller percentages. A set of smaller effects can change the relative sizes of some sector output changes, but generally have smaller importance, such as the composition of consumption. In the simulations, the high income household and the low income household have most of the welfare and income gains, so products that are consumed more intensively by those households than the other households have a larger increase in demand.

The largest industry expansions occur in those sectors that sell a larger proportion of their output to foreign tourists, such as accommodation, travel agency and transportation sectors. The sectors that contract the most are related to export activities, but the relatively diverse structure of Brazilian exports means that the contractionary effects are spread widely across many sectors, so that the largest contraction ( 0.23 in footwear) is smaller than the ninth largest expansion.

Table 4 shows the percentage change in real wages accruing to each factor of production. Clearly, from this table, the wage changes are robust to changes in the way that the government transfers additional income. Employers' labor has the highest increase in real wage following the tourism expansion, followed by self employed labor and semi skilled 
labor. The effects on unskilled and skilled labor wages are small. Returns to capital fall notably, by around $0.03 \%$, which reflects the low capital to labor ratios in most tourism related industries in Brazil.

\section{[INSERT TABLE 4 AROUND HERE]}

Table 5 shows how the composition of real earnings changes due to a $10 \%$ increase in foreign tourism demand, by household. Column 1 shows the direct earnings effects, which are the earnings by household in the sector from which foreign tourists are purchasing goods and services. This is calculated as the sum across factors of production of the proportion of that factor's earnings that accrue to household $\mathrm{h}, \quad\left(\alpha_{h, f}\right)$ multiplied by, for each sector, ten percent of tourism demand $\left(D_{i} \times 0.1\right)$ multiplied by the proportion of earnings by factor $\mathrm{f}$ in sector i sales $\left(\alpha_{f, i}\right): D E_{h}=\sum_{f} \alpha_{f, h} \sum_{i} \alpha_{f, i} D_{i} \times 0.1$

\section{[INSERT TABLE 5 AROUND HERE]}

These effects show that direct earnings are spread across all households, with the low income household earning more $(\mathrm{R} \$ 73 \mathrm{~m})$ than other households. The direct plus indirect effects of tourism expansion are calculated in a similar manner to the direct effects, except that ten percent of direct sales $\left(D_{i} \times 0.1\right)$ are replaced by the direct plus indirect sales resulting from a $10 \%$ increase in foreign tourism $\left(S_{i}\right): D E_{h}=\sum_{f} \alpha_{f, h} \sum_{i} \alpha_{f, i} S_{i} . S_{i}$ is then calculated using an input output model $S=(I-A)^{-1}(D \times 0.1)$. The results in column 2 show that the indirect earnings effects are highly significant for the high income household, which earns more through the indirect effects than through the direct effects of tourism expansion.

The CGE model results (from Table 3) are decomposed into earnings, prices and government channels as well as the effects of increased firm investment (columns 3 to 6 in Table 5). The results show that the total earnings effects (column 3) are often lower than the direct plus indirect earnings effects; and that for the medium and high income households, the total earnings effects are small. Other export sectors are much more intensive in their use of factors of production - capital and skilled labor - that are owned by the richer household groups, than are tourism related industries. The greatest burdens of the crowding out activities therefore fall on the medium and high income households. The price channel (column 4) is shown to have a moderate effect, increasing the real income of the poorest household groups but 
reducing the real income of the richest household group. The government channel (column 5), in this simulation, acts to increase the incomes of all households except the poorest as the poorest households receive very low levels of transfers. The firms effect (column 6) comes through the fact that firms invest more in response to the tourism shock, and the additional holding of capital (with future earnings potential) is allocated to households in proportion to their ownership of firms.

\section{CONCLUSION}

This paper has provided an economy-wide analysis of the distributional effects of tourism expansion, providing a means of answering the question of whether and how tourism can contribute to poverty relief. A computable general equilibrium modelling approach was developed to include earnings by different categories of workers in the tourism industry and households with different levels of income, as well as the channels by which tourism affects the distribution of income between rich and poor households. The channels by which the distributional effects occur are changes in prices, earnings and the government.

The model was calculated using a dataset that is unique in the context of developing countries, in that it includes detailed data for earnings by different types of labor and capital in different sectors of the economy. The results show that, when taking all the negative or offsetting effects into account, as well as the positive effects of tourism expansion, there is a multiplier of 0.45 . This is the welfare gain to Brazil of every $\mathrm{R} \$ 1$ unit of additional tourism spending. The results also show that tourism benefits the lowest income sections of the Brazilian population and has the potential to reduce income inequality.

The lowest income households are not, however, the main beneficiaries of tourism, as households with low (but not the lowest) income benefit more from the earnings and price channel effects of tourism expansion. High income and medium income households, followed by low income households, benefit most from the government channel effects, with the exception of the case when government directs the revenue from tourism expansion specifically towards the lowest income group. The latter type of revenue distribution by the government could double the benefits for the lowest income households, giving them around one-third of all the benefits from tourism. The implication is that government policies directed specifically towards benefiting the lowest income group are required if the poorest are to achieve the greatest gains. 
The results from this study have shown that care needs to be taken when generalising poverty relief results. In the case of Brazil, there is a strong reinforcement effect whereby the industries that reduce their output following a tourism demand increase are export industries that employ factors of production from the richer households. The structure of earnings in non-tourism export sectors therefore plays a significant role in determining the net poverty effects of tourism. This type of earnings structure may not apply in other countries. Hence, it would be interesting to apply the model to tourism expansion in other countries, in order to investigate the effects that would occur under different types of earnings structures.

Further research using this model would also be of interest. One of the limitations of using representative household groups (the four types of households in this model) is that there is significant heterogeneity within these groups. For this reason, more detailed household modelling would be desirable, using a microsimulation approach to the household impacts, in which data on individual households are intrinsic to the model.

\section{REFERENCES}

Adams, P. and B. Parmenter,

1995 An Applied General Equilibrium Analysis of the Economic Effects of Tourism in a

Quite Small, Quite Open Economy. Applied Economics, 27:985-994.

Alavalapati, J. and W. Adamowicz

2000 Tourism Impact Modeling for Resource Extraction Regions. Annals of Tourism Research, 27(1):188-202.

Arbache, J., V. Teles. N. da Silva and S. Cury

2004 Social Accounts Matrix of Brazil for Tourism - 2002. Center of Excellence in

Tourism - Core of Economy of Tourism - CET/NET.

Archer, B.

1995 Importance of Tourism for the Economy of Bermuda. Annals of Tourism Research 22: $918-930$.

1996 Economic Impact Analysis. Annals of Tourism Research 23(3):704-707.

Archer, B. and J. Fletcher

1996 The Economic Impact of Tourism in the Seychelles, Annals of Tourism Research 23: 32-47.

Ashley, C. and D. Roe

2002 Making Tourism work for the Poor: Strategies and Challenges in Southern Africa.

Development Southern Africa 19(1): 61-82.

Blake, A.

2000 The Economic Impact of Tourism in Spain, TTRI Discussion Paper no. 2000/2.

Blake, A. and M.T. Sinclair

2003 Tourism and Crisis Management: US Response to September 11, Annals of Tourism Research, 30(4): 813-32.

Blake, A., Sinclair, M.T. and G. Sugiyarto

2003 Quantifying the Impact of Foot and Mouth Disease on Tourism and the UK Economy, Tourism Economics, 9(4): 449-63. 
Dwyer, L, Forsyth, P., Madden, J. and R. Spurr

2000 Economic Impacts of Inbound Tourism under Different Assumptions regarding the Macroeconomy. Current Issues in Tourism, 3(4):325-363.

2003a Inter-industry Effects of Tourism Growth: Implications for Destination Managers.

Tourism Economics, 9(2):117-132.

Dwyer, L, P. Forsyth, R. Spurr and T. Ho

2003b The Contribution of Tourism to a State Economy: a Multi-regional General

Equilibrium Analysis. Tourism Economics 9(4): 431-48.

Dwyer, L., Forsyth, P. and R. Spurr

2004 Evaluating Tourism's Economic Effects: New and Old Approaches, Tourism Management, 25(3):307-17.

Ferreira, F. G. H., P. G. Leite and J. A. Litchfield.

2006 The Rise and Fall of Brazilian Inequality, 1981-2004, World Bank Policy Research

Working Paper WPS3867.

Fletcher, J.

1989 Input-Output Analysis and Tourism Impact Studies. Annals of Tourism Research 16:

514-529.

Gooroochurn, N. and M.T. Sinclair

2005 Economics of Tourism Taxation: Evidence from Mauritius, Annals of Tourism Research 32(2):478-98.

Kraev, E. and B. Akolgo

2005 Assessing Modelling Approaches to the Distributional Effects of Macroeconomic

Policy, Development Policy Review 23(3):299-312.

McCulloch, N., L. A. Winters and X. Cirera

2001 Trade Liberalization and Poverty: A Handbook. CEPR

Minestério do Turismo

2003 National Tourism Plan 2003-2007, Brazil.

Roe, D., C. Ashley, S. Page and D. Meyer

2004 Tourism and the Poor: Analysing and Interpreting Tourism Statistics from a Poverty

Perspective, Pro-Poor Tourism Working Paper No. 16. Pro-Poor Tourism: London. www.propoortourism.org.uk

Sinclair, M. T.

1998 Tourism and Economic Development: A Survey, Journal of Development Studies 34

(5):1-51.

Sugiyarto, G., Blake, A. and M.T. Sinclair

2003 Tourism and Globalisation: Economic Impact in Indonesia, Annals of Tourism

Research 30(3):683:701.

Wanhill, S., 1994

The Measurement of Tourist Income Multipliers, Tourism Management 15(4):281-283.

World Bank

2005 World Development Indicators CD-ROM. World Bank: Washington D.C.

World Tourism Organisation

2005 International Tourist Arrivals and Tourism Receipts by Country. WTO: Madrid.

Zhou, D., J. Yanagida, U. Chakravorty and L. Ping Sun

1997 Estimating Economic Impacts from Tourism, Annals of Tourism Research 24(1):76-

89. 
Table 1: Indicators of the Tourism Sector in the Brazilian Economy, 2002

\begin{tabular}{lccc}
\hline & $\begin{array}{c}\text { Brazil } \\
\text { (R\$ billion) }\end{array}$ & $\begin{array}{c}\text { Tourism } \\
\text { (R\$ billion) }\end{array}$ & $\begin{array}{c}\text { Tourism as a } \\
\text { Share of Total } \\
(\%)\end{array}$ \\
\hline GDP & $1,395.21$ & 77.58 & $5.56 \%$ \\
Remuneration & & & \\
Skilled labor & 194.54 & 8.42 & $4.33 \%$ \\
Semi skilled labor & 35.84 & 2.61 & $7.29 \%$ \\
Unskilled labor & 73.92 & 4.53 & $6.13 \%$ \\
Self employed labor & 61.62 & 8.17 & $13.25 \%$ \\
Employers' labor & 47.37 & 2.53 & $5.34 \%$ \\
Capital & 564.32 & 3.79 & $0.67 \%$ \\
Indirect Taxes & 161.47 & 8.58 & $5.32 \%$ \\
Foreign currency revenue & 196.35 & 7.77 & $3.96 \%$ \\
Consumption & & & \\
Lowest income households & 61.2 & 3.0 & $4.9 \%$ \\
Low income households & 154.8 & 5.2 & $3.4 \%$ \\
Medium income households & 154.9 & 8.1 & $5.2 \%$ \\
High income households & 354.0 & 40.2 & $11.3 \%$ \\
Earnings & & & \\
Lowest income households & 51.96 & 4.32 & $8.3 \%$ \\
Low income households & 143.05 & 10.19 & $7.1 \%$ \\
Medium income households & 103.65 & 6.21 & $6.0 \%$ \\
High income households & 183.80 & 9.33 & $5.1 \%$ \\
\hline Note: Skiled & & & \\
\hline
\end{tabular}

Note: Skilled labor: 11+ years of schooling; Semi skilled labor: 7 to 11 years of schooling; Unskilled labor: less than 7 years of schooling; Lowest income households: up to R\$ 100 per capita per month; Low income households: R\$ 101 to R\$ 300 per capita; Medium income households: R\$ 301 to R\$ 600 per capita; High income households: R $\$ 601+$ per capita.

Source: Arbache et al. 2004 
Table 2: Tourism Related Commodities

\begin{tabular}{|c|c|c|c|c|c|}
\hline & \multicolumn{2}{|c|}{ Foreign tourism } & \multicolumn{2}{|c|}{ Domestic tourism } & \multirow{2}{*}{$\begin{array}{c}\text { Total } \\
\text { Share of total } \\
\text { demand for } \\
\text { product }\end{array}$} \\
\hline & $\begin{array}{l}\text { Share of } \\
\text { total demand } \\
\text { for product }\end{array}$ & $\begin{array}{l}\text { Share of } \\
\text { foreign } \\
\text { tourism } \\
\text { expenditure }\end{array}$ & $\begin{array}{l}\text { Share of } \\
\text { total } \\
\text { demand } \\
\text { for product }\end{array}$ & $\begin{array}{c}\text { Share of } \\
\text { domestic } \\
\text { tourism } \\
\text { expenditure }\end{array}$ & \\
\hline Regular transportation of passengers by land & $6 \%$ & $16 \%$ & $53 \%$ & $14 \%$ & $59 \%$ \\
\hline Non-regular transportation of passengers by land & $6 \%$ & $1 \%$ & $53 \%$ & $1 \%$ & $59 \%$ \\
\hline Specialized transportation to visit tourism places & $4 \%$ & $0 \%$ & $62 \%$ & $0 \%$ & $66 \%$ \\
\hline Regular airline transportation & $0 \%$ & $0 \%$ & $65 \%$ & $15 \%$ & $65 \%$ \\
\hline Non-regular airline transportation & $0 \%$ & $0 \%$ & $65 \%$ & $1 \%$ & $65 \%$ \\
\hline Travel agencies & $11 \%$ & $6 \%$ & $6 \%$ & $0 \%$ & $17 \%$ \\
\hline Support activities to land transportation & $12 \%$ & $2 \%$ & $22 \%$ & $0 \%$ & $34 \%$ \\
\hline Support Activities to airline transportation & $12 \%$ & $2 \%$ & $22 \%$ & $0 \%$ & $34 \%$ \\
\hline Hotels and other temporary lodging & $26 \%$ & $37 \%$ & $56 \%$ & $9 \%$ & $81 \%$ \\
\hline Restaurants and other food service enterprises & $8 \%$ & $35 \%$ & $77 \%$ & $38 \%$ & $85 \%$ \\
\hline Recreation, cultural and sports services & $0 \%$ & $1 \%$ & $71 \%$ & $20 \%$ & $72 \%$ \\
\hline \multirow[t]{2}{*}{ Car rental and other transportation } & $3 \%$ & $0 \%$ & $35 \%$ & $0 \%$ & $38 \%$ \\
\hline & & $100 \%$ & & $100 \%$ & \\
\hline
\end{tabular}


Table 3: Main Results for Tourism and Welfare

\begin{tabular}{|c|c|c|c|c|}
\hline Simulation & 1 & 2 & 3 & 4 \\
\hline $\begin{array}{l}\text { Closure rule: additional } \\
\text { government income is transferred } \\
\text { in proportion to... }\end{array}$ & $\begin{array}{l}\text { Original transfer } \\
\text { receipts }\end{array}$ & $\begin{array}{l}\text { Levels of income } \\
\qquad \operatorname{tax}\end{array}$ & $\begin{array}{l}\text { Levels of } \\
\text { income }\end{array}$ & $\begin{array}{l}\text { Only to the } \\
\text { poorest } \\
\text { household }\end{array}$ \\
\hline $\begin{array}{l}\% \text { change in tourism } \\
\text { consumption }\end{array}$ & 8.484 & 8.484 & 8.484 & 8.484 \\
\hline$\%$ change in tourism price & 0.697 & 0.697 & 0.697 & 0.696 \\
\hline$\%$ change in tourism expenditure & 9.239 & 9.239 & 9.239 & 9.240 \\
\hline $\begin{array}{l}\text { Change in tourism expenditure } \\
(\mathrm{R} \$ \mathrm{bn})\end{array}$ & 0.680 & 0.679 & 0.680 & 0.680 \\
\hline Equivalent Variation (R\$bn) & 0.309 & 0.309 & 0.309 & 0.305 \\
\hline $\begin{array}{l}\text { EV as a percentage of original } \\
\text { income }\end{array}$ & 0.025 & 0.025 & 0.025 & 0.025 \\
\hline \multicolumn{5}{|l|}{ Compensated EV (R\$bn) } \\
\hline Lowest income household & 0.053 & 0.053 & 0.058 & 0.108 \\
\hline Low income household & 0.111 & 0.106 & 0.110 & 0.097 \\
\hline Medium income household & 0.028 & 0.031 & 0.023 & 0.012 \\
\hline High income household & 0.116 & 0.119 & 0.118 & 0.088 \\
\hline $\begin{array}{l}\text { Percentage change in } \\
\text { Highest:Lowest real income }\end{array}$ & -0.035 & -0.034 & -0.039 & -0.092 \\
\hline \multicolumn{5}{|l|}{$\mathrm{EV}$ as percentage of total EV } \\
\hline Lowest income household & $17 \%$ & $17 \%$ & $19 \%$ & $35 \%$ \\
\hline Low income household & $36 \%$ & $34 \%$ & $36 \%$ & $32 \%$ \\
\hline Medium income household & $9 \%$ & $10 \%$ & $7 \%$ & $4 \%$ \\
\hline High income household & $38 \%$ & $39 \%$ & $38 \%$ & $29 \%$ \\
\hline
\end{tabular}


Table 4: Percentage Change in Real Wages

\begin{tabular}{|c|c|c|c|c|}
\hline Simulation & 1 & 2 & 3 & 4 \\
\hline $\begin{array}{l}\text { Closure rule: additional } \\
\text { government income is } \\
\text { transferred in proportion to... }\end{array}$ & $\begin{array}{l}\text { Original transfer } \\
\text { receipts }\end{array}$ & $\begin{array}{l}\text { Levels of income } \\
\qquad \operatorname{tax}\end{array}$ & Levels of income & $\begin{array}{c}\text { Just to the poorest } \\
\text { household }\end{array}$ \\
\hline Unskilled labor & 0.008 & 0.008 & 0.008 & 0.008 \\
\hline Semi skilled labor & 0.013 & 0.013 & 0.013 & 0.012 \\
\hline Skilled labor & 0.001 & 0.001 & 0.001 & 0.000 \\
\hline Self employed labor & 0.018 & 0.018 & 0.018 & 0.017 \\
\hline Employers' labor & 0.074 & 0.074 & 0.074 & 0.073 \\
\hline Capital & -0.033 & -0.033 & -0.033 & -0.032 \\
\hline
\end{tabular}

Table 5: Distribution of Earnings by Household, $\mathrm{R} \$$ million

\begin{tabular}{lcccccc}
\hline & 1 & 2 & 3 & 4 & 5 & 6 \\
& Direct effect & $\begin{array}{c}\text { Direct plus } \\
\text { indirect effects }\end{array}$ & & & & \\
& & & & & & \\
& earnings & earnings & earnings & prices & government & firms \\
\hline Lowest income household & 32 & 43 & 34 & 4 & 0 & 16 \\
Low income household & 73 & 103 & 74 & 12 & 14 & 0 \\
Medium income household & 41 & 65 & 9 & 2 & 17 & 11 \\
High income household & 54 & 115 & 19 & -18 & 31 & 84 \\
\hline
\end{tabular}




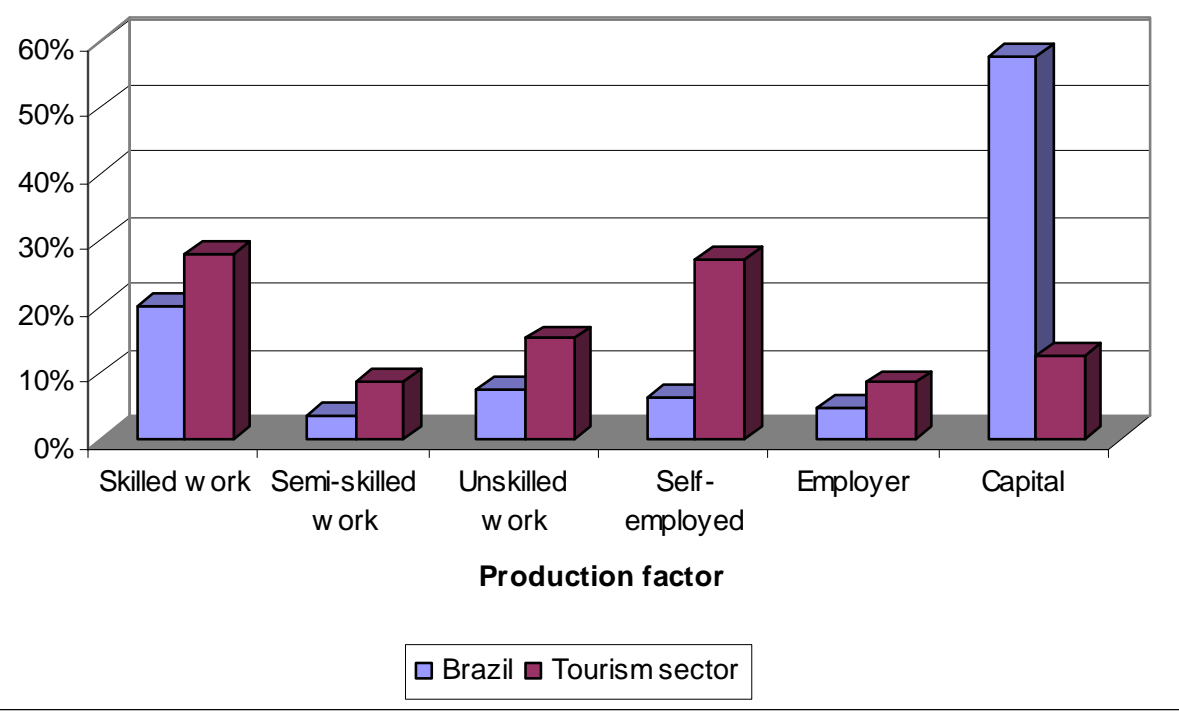

Source: Arbache et al. 2004

Figure 1: Income Distribution by Production Factor, Brazil, 2002 